\title{
Effect of allithiamine on the level of hyperglycaemia-induced advanced glycation end products
}

\author{
Attila Biró - Judit Remenyik \\ Institute of Animal Science, Biotechnology and Nature Conservation, Institute of Food Technology, University of Debrecen, H-4032 \\ Debrecen, Hungary \\ attila.biro88@gmail.com
}

\begin{abstract}
SUMMARY
Diabetes mellitus is a rapidly growing public health burden in both developed and developing countries. Diabetes mellitus is accompanied by hyperglycaemia, which can cause tissue injury by several mechanisms. One of these is the formation of advanced glycation end-products (AGEs). In this study, the effect of allithaimine, a fat-soluble thiamine derivative, was investigated on hyperglycaemia-induced AGEs levels using human umbilical cord vein endothelial cells (HUVECs) as a hyperglycaemic model. HUVECs were isolated by enzymatic digestion, characterized by flow cytometer and treated $30 \mathrm{mM}$ glucose plus allithaimine or thiamine or cell maintenance medium as control. Allithiamine was synthesized and purified. The structure of the synthesized and isolated compound was verified by reverse phase HPLC and MALDI-TOF. AGEs were evaluated by ELISA. Collectively, our results indicate that allithiamine can reduce level of the hyperglycaemia-induced AGEs similar to thiamine.
\end{abstract}

Keywords: allithiamine, hyperglycaemia, advanced glycation end-products, endothelial cells

\section{INTRODUCTION}

Thiamine, known as vitamin B1, has pivotal role in energy metabolism (Lonsdale, 2006). Thiamine is the main compound of thiamine pyrophosphate which is a cofactor of enzymes involved in glucose metabolism. Allithiamine is a lipid soluble form of vitamin B1, which was found firstly in Allium genus (Fujiwara et al., 1954). In our preliminary experiment, the effect of allithiamine was investigated in streptozotocin-induced diabetic mice. The results confirm the improvement of neuropathic pain sensation (Biro et al., 2018).

Diabetes mellitus $(\mathrm{DM})$ is a metabolic endocrine disorder with serious micro- and macrovascular complications. The latest prognosis of the World Health Organization (WHO) predicted an increasing prevalence of DM. DM is accompanied by hyperglycaemia, which may cause tissue damage by several mechanisms (Berrone at al., 2006). One of the major metabolic route is the nonenzymatic glycation of intra- and extracellular proteins, lipids, nucleic acids resulting in advanced glycation end-products (AGEs) (Nin et al., 2011). Increased level of AGEs leads to harmful intermediates causing enhanced oxidative stress and consequential inflammation (Zhang et al., 2003). Several studies suggest that the increased formation of AGEs is major cause of endothelial dysfunction in DM. It has been suggested that unphosphorlylated thiamine and its synthetic derivatives can alleviate endothelial dysfunction by inhibiting AGEs pathway (Balakumar et al., 2010; Brownlee, 2005). The object of this study was to examine effect of allithiamine compared to thiamine in primary cultured human umbilical cord vein endothelial cells (HUVECs) as hyperglycaemic model investigating level of AGEs.

\section{MATERIALS AND METHODS}

\section{Preparation, purification and verification of pure allithiamine}

Synthesis of allithiamine was carried out based on the experiments by Biro et al. Briefly, allyl thiosulphate resulting from the reaction of allyl chloride with sodium thiosulfate was reacted with thiamine hydrochloride with open thiazole ring resulted in different thiamine derivatives. Thiamine derivatives were separated using reversed phase HPLC system. Measurements were carried out using Merck-Hitachi LaChrom liquid chromatograph, equipped with diode array detector L-7455, automatic sampler L-7250 interface L-7000, pump L7100 and HPLC System Manager Software. Allithiamine was analysed on a LiChroCART ${ }^{\circledR}$ 250-10 RP-18 column (12 $\mu$ m) using gradient elution. MALDI spectra of allithiamine samples were obtained in positive-ion mode using a Bruker Biflex MALDI-TOF mass spectrometer equipped with delayed-ion extraction.

\section{Cell culture and allithiamine treatments}

The human umbilical vein endothelial cells (HUVECs) were isolated from human umbilical cords. Umbilical cords were obtained from Department of Obstetrics and Gynaecology. Enzymatic digestion of HUVECs was performed by $22 \mathrm{U} / 100 \mathrm{~mL}$ collagenase solution incubating for $15 \mathrm{~min}$ at $37^{\circ} \mathrm{C}$. HUVECs were grown using M199 medium supplemented with $10 \%$ heat-inactivated FBS, $1 \%$ penicillin/streptomycin, $1 \%$ Amphotericin B, 2 mM glutamine and Endothelial Cell Growth Medium-2 (EGM-2) at $37^{\circ} \mathrm{C}$ in a humidified incubator under $5 \% \mathrm{CO}_{2}$. Media was changed every two days until cells reached around $90 \%$ confluency. At confluency, cells were either subcultured or used for experiments. Media as described above was used as control and had 5.6 mM D-glucose. For high glucose treatment, D-glucose was added to M199 for a final 
concentration of $30 \mathrm{mM}$. Cells were divided in four groups: $24 \mathrm{~h}$ incubating with $5 \mathrm{mM}$ glucose (Control), $24 \mathrm{~h}$ incubating with $30 \mathrm{mM}$ glucose (HG), $24 \mathrm{~h}$ incubating with $30 \mathrm{mM}$ glucose then $15 \mu \mathrm{M}$ allithiamine was added (HG-AT) and $24 \mathrm{~h}$ incubating with $30 \mathrm{mM}$ glucose then $50 \mu \mathrm{M}$ thiamine (HG-BT) was added. Cells were incubated for one week prior to determination of AGEs formation.

\section{Flow cytometry studies}

For identifications of HUVECs, flow cytometry measurements were performed. Cells were incubated with four kind of antibody labelled by fluorescent dye for 30 minutes at room temperature in dark. Approximately 100,000 cells were used for one measurement. Cell counting was performed using a Bürker chamber. FITC-labelled mouse anti-human CD31, PE-labelled mouse anti-human CD54, APClabelled mouse anti-human CD106 and PerCP-Cy5.5 labelled mouse anti-human CD45 was used for labelling. The measurements were carried out using a Becton Dickinson FACSAria ${ }^{\mathrm{TM}}$ III Cell Sorter (Becton Dickinson, Mountain View, CA, USA). Circa 20000 cells/sample were recorded and analysed. Cytofluorimetric data were analysed by using FCS Express 4 Research Edition (De Novo Software, Glendale, CA, USA).

\section{Measurement of advanced glycation end-products}

The assay was performed according to the manufacturer's instructions using OxisSelect ${ }^{\mathrm{TM}}$ Advanced Glycation End Product (AGE) Competitive ELISA Kit (Cell Biolabs Inc., San Diego, California). Protein determination required for normalization were determined in the cell lysate using Pierce ${ }^{\mathrm{TM}}$ BCA Protein assay (Pierce Biotechnology, Rockford, USA). All measurements were performed with the microplate reader (SPECTROstar ${ }^{\text {Nano }}$, BMG Labtech, Ortenberg, Germany).

\section{Statistical analysis}

For multiple comparisons, results were analysed by ANOVA followed by modified t-test for repeated measures according to Tukey's method. Data were presented as mean \pm SEM. $\mathrm{P}<0.05$ was considered statistically significant.

\section{RESULTS AND DISCUSSION}

\section{Verification of pure allithiamine}

Preparation of allithiamine resulted in a wide variety of thiamine and other by-products as we experienced. Derivatives were separate by HPLCmethod. Allithiamine was eluted at $30.5 \mathrm{~min}$ (shown in Figure 1), as we identified with MALDI-TOF (data not shown).

Figure 1: HPLC chromatogram of allithiamine

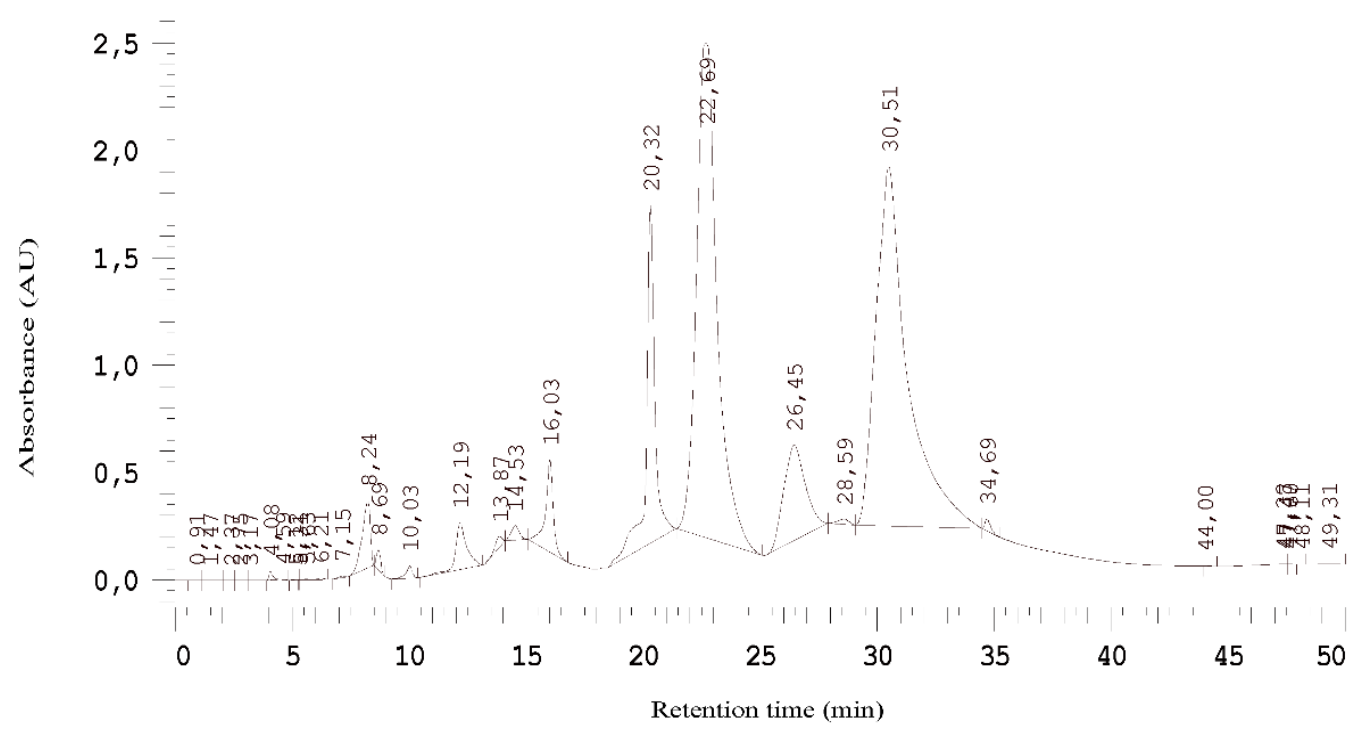

\section{Characterization of HUVECs by flow cytometer}

Isolated HUVEC cells were characterized for positive and negative marker expression using flow cytometry and antibodies against specific marker proteins: CD54, CD31, CD45 and CD106. As it is shown in Figure 2 isolated HUVECs showed high
CD54 and CD31 positive marker expression levels (app. $76 \%$ double positive cells) while app. $94 \%$ of cells did not express CD45 and CD106 markers strongly suggesting the high accuracy and efficiency of cell isolation. 
Figure 2: Flow cytometry analysis of HUVEC cells
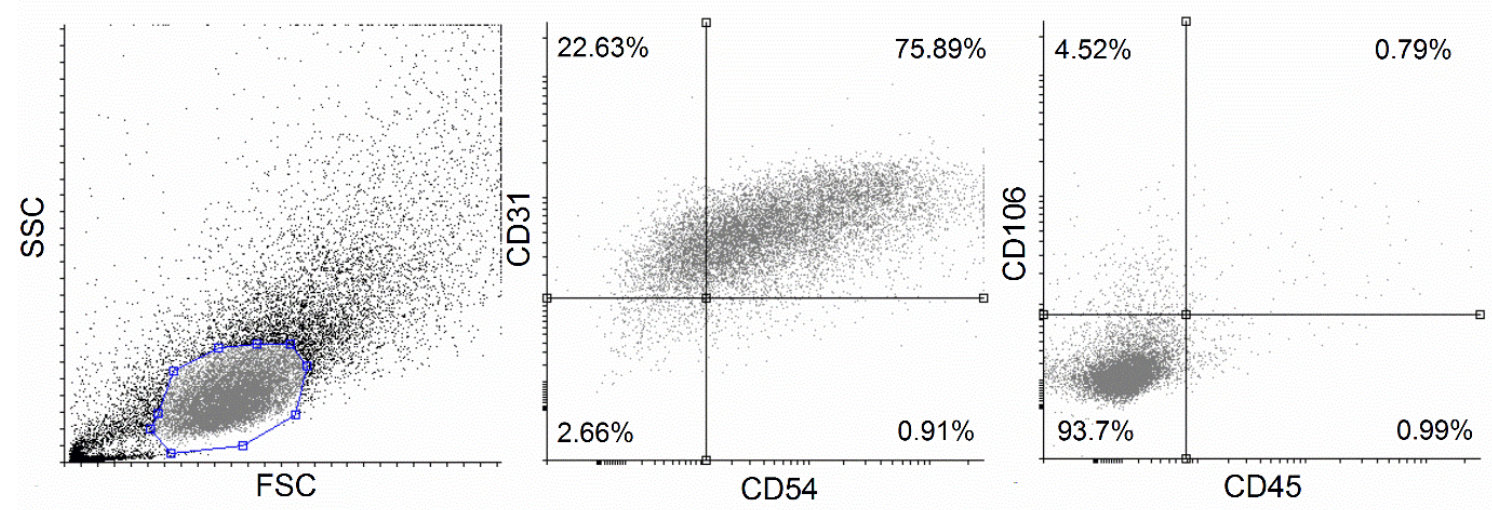

Level of advanced glycation end-products (AGEs)

AGEs are one of the most important pathogenetic factor in the development and progression of both microvascular and macrovascular damages (Brownlee, 2001). AGEs were measured in the cells incubated with $5 \mathrm{mM}$ glucose, $30 \mathrm{mM}$ glucose, $30 \mathrm{mM}$ glucose and 15 $\mu \mathrm{M}$ allithiamine or $50 \mu \mathrm{M}$ thiamine. Amount of AGEs were evaluated after one-week incubations in all groups. The data of the 5- 6- and 7-day incubations were shown on the Figure 3. Positive correlation was shown in the levels of AGEs and hyperglycaemia. Both allithiamine and thiamine alleviate the hyperglycaemia-induced increase of AGEs significantly. * indicates significant difference on level of AGEs between HG and Control, HG-AT, HG-BT group on the figure.

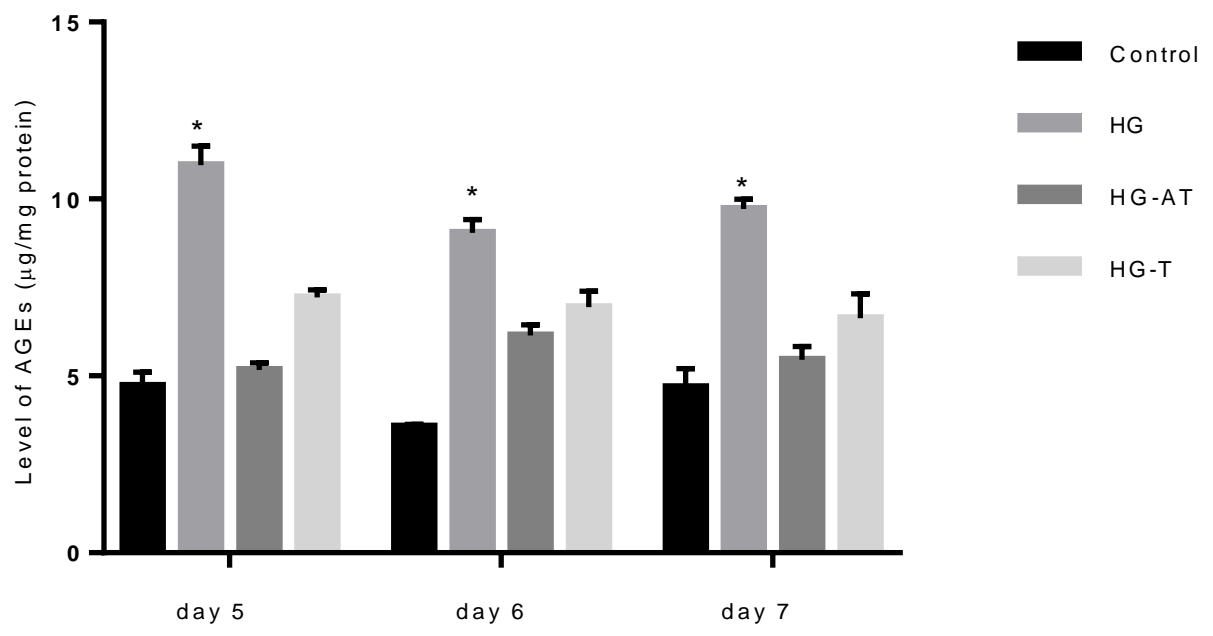

\section{CONCLUSION}

The object of this study was to examine the effect of allithiamine compared to thiamine in primary cultured human umbilical cord vein endothelial cells as hyperglycaemic model investigating level of advanced glycation end-products. We found that allithiamine has a beneficial effect on the level of hyperglycaemiainduced AGEs similar to thiamine. As it is known, thiamine is a cofactor of enzymes involved in glucose metabolism (pyruvate dehydrogenase, transketolase, $\alpha$-ketoglutarate-dehydrogenase) which may play a role in its positive effects (Kern et al., 1997). Chemical structural similarity suggest that allithiamine may have an analogue influence on glucose metabolism. It is assumed that allitiamin is able to increase the activity of these enzymes with particular regard to transketolase activity. Increasing transketolase activity has been shown to reduce the flux of metabolic pathways involved in the patomechanism of hyperglycaemia (Nishimura, 1998); (Geraldes and King, 2010) including the AGE-pathway. As regards particular mechanisms of action and possible clinical value, further investigations are needed to confirm our findings. 


\section{REFERENCES}

Balakumar, P.-Rohilla, A.-Krishan, P.-Solairaj, P.Thangathirupathi, A. (2010): The multifaceted therapeutic potential of benfotiamine. Pharmacological research 61: 482488

Berrone, E.-Beltramo, E.-Solimine, C.-Ape, A. U.-Porta, M. (2006): Regulation of intracellular glucose and polyol pathway by thiamine and benfotiamine in vascular cells cultured in high glucose. J Biol Chem 281: 9307-9313.

Biro, A.-Gál, F.-Hegedűs, Cs.-Batta, Gy.-Cziáky, Z.-Peitl, B.Stündl, L.-Gyémánt, Gy.-Remenyik, J. (2018): Isolation of allithiamine from Hungarian red sweet pepper seed (Capsicum anпиит L.) Heliyon 4(12)

Brownlee, M. (2001): Biochemistry and molecular cell biology of diabetic complications. Nature 414: 813-20.

Brownlee, M. (2005): The pathobiology of diabetic complications: A unifying mechanism. Diabetes 54: 1615-1625.

Fujiwara, M.-Watanabe, H.-Matsui, K. (1954): Allithiamine a newly found derivative of vitamin B1 discovery of allithiamine. The Journal of Biochemistry 41: 29-39.

Geraldes, P.-King, G. L. (2010): Activation of protein kinase C isoforms and its impact on diabetic complications. Circ Res. 106(8): 1319-31
Kern, D.-Kern, G.-Neef, H.-Tittmann, K.-Killenberg-Jabs. M.Wikner, C.-Schneider, G.-Hubner, G. (1997): How thiamine diphosphate is activated in enzymes. Science 275: 67-70.

Lonsdale, D. (2006): A review of the biochemistry, metabolism and clinical benefits of thiamin(e) and its derivatives. Evid Based Complement Alternat Med 3: 49-59.

Nin, J. W.-Jorsal, A.-FerreiraI.-Schalkwijk, C. G.-Prins, M. H.Parving, H. H.-Tarnow, L.-Rossing, P.-Stehouwer, C. D. (2011): Higher plasma levels of advanced glycation endproducts are associated with incident cardiovascular disease and all-cause mortality in type 1 diabetes:a 12-year follow-up study. Diabetes Care 34(2): 442-7.

Yabe-Nishimura, C. (1998): Aldose reductase in glucose toxicity: a potential target for the prevention of diabetic complications. Pharmacol Rev. 50(1):21-33.

Zhang, L.-Zalewski, A.-Liu, Y.-Mazurek, T.-Cowan, S.-Martin, J. L.-Hofmann, S. M.-Vlassara, H.-Shi, Y. (2003): Diabetesinduced oxidative stress andl ow- grade inflammation in porcine coronary arteries Circulation 108: 472-478. 